\title{
ANNALS OF IOWA
}

\begin{tabular}{|c|c|c|}
\hline VoL. XVI, No. 8 & Drs Moines, ApriL, 1929 & 'H'HJRI SFRIES \\
\hline
\end{tabular}

PIONEER LAWMAKERS ASSOCIATION

\section{By David C. Mott, Secretary}

'The Twenty-first session of the Pioneer Lawmakers' Association of Iowa met in the Portrait Gallery of the Historical, Memorial and Art Department, Des Moines, on February 13, 1929. Owing to the death of the president, H. W. Byers, the vice president, George W. Clarke, presided. Invocation was offered by Rev. Charles Blanchard of the Christian church, at present a research worker in the Historical Department. Justice Truman $S$. Stevens then delivered an address of welcome in which he spoke of the progress and growth of legislation as viewed from the bench. He said he had often thought he would greatly enjoy a term in the legislature for the experience and pleasure of it as well as to bear his part of the burden. His address was greatly appreciated by the members of the association and we regret we are unable to give the complete text here. It was responded to by former Representative Van Houten.

\section{RESPONSE TO ADDRESS OF WELCOME \\ By George H. VAN Hou'ten}

Mr. President and Members of Pioneer Lawmakers' Association: I im sure we appreciate the kindly words of welcome of Judge Stevens: not only as to the welcome extended but also we are appreciative of the remarks made.

It is pleasant to receive the words of commendation he has given, for they are in contrast to denunciations of many people and some of the papers, especially the daily papers, for they insist that too many laws are on the statute books and that laws should be repealed, rather than more laws enacted. Some go so far as to say that each legislator should be empowered to repeal at least one law, and yet laws for repeal are not singled out, but such papers criticise unsparingly; and yet in most cases such papers have certain pet measures that they insist should be cnacted into laws, and seem very anxious and earnest that legislators should pay attention to the measures advocated.

But we as legislators in the past are not the only ones that are held 
up for criticism; our courts come in for a share of denunciation, and often harsh criticisms are heard. The courts are blamed for the nonenforcement of laws and many cases are cited where criminals or those accused of crimes are allowed to escape. There may be technicalities and other instances where the accused are allowed to escape punishment for crimes committed, and yet we seldom hear criticisms while the cases are pending and immediately after the rulings are made, but only after the trial is over and the jury fails to convict.

I apprehend that the courts are not always to blame, for there may be cases where verdicts of guilty should be rendered, where no decisions are made, and possibly lack of conviction is not due to the court. Let me give the result of a discussion recently heard that will illustrate my point: A gentleman that I did not know, was airing his views and in positive and persistent language and often repeated, said that he would under no circumstance bring In a verdict of guilty on circumstantial evidence. When we consider that premeditated murders are seldom committed before would-be witnesses, it is easily seen that a criminal would escape with such a juror as this. And again, often where robbery is committed the criminal kills the victim, in which case there usually would be only circumstantial evidence. Many of our worst highwaymen go on the theory that "dead men tell no tales," and frequently in such cases only circumstantial evidence can be produced.

A woman was present and combatted this theory of only convicting on circumstantial evidence, but she asserted that she would not give a verdict of guilty if it should be in the power of the judge to give the death penalty, and upon being questioned asserted that she would do anything under God's heaven to prevent the death penalty. Now, with either of those people on the jury there would be little chance for conviction, especially if the accusation was murder, for there would be at least one who would demand living witnesses, and another that would insist that some other verdict than murder should be meted out. And besides that, there are others who feel the same way, and it is easy to contend that there is "a reasonable doubt," in most cases. So it seems to me that our courts are not to blame in all cases where criminals are not convicted.

Again, we hear comparisons made as between our country and foreign lands, where, it is asserted, criminals are convicted and order prevails. It may be that such critics have seen more of foreign lands than have I, but in my observations the comparisons are unjust. I agree that some things forbidden by law here are permitted in some countries. In some of the countries recently visited, there is hardly room for comparisons, and yet there are chances for contrasts.

Of all the countries of the Old World, it seems to me that England comes the nearest in laws and customs to our own country. England is by some considered the "Mother Country," and from which our language, laws and customs came. Now let us consider the difference between the United States and England: Here we have prohibition-at least the 
Constitutional Amendment and the Volstead Act, and the people ap- prove, and, as I believe, in most places the law is enforced. It has been my privilege to have crossed the continent since prohibition came and visited many portions, and I believe that in most places the law is as well enforced as some other laws about which there is no dispute.

But now let us consider England: There is the open saloon, or the bars as they are called, and almost invariably kept by young women, and any suggestion of prohibition there brings forth the active protest that it would throw thousands of young women out of employment. Of course, if we, like England, had no law against the sale of intoxicating liquor, there would be no violation, and in few if any of the many countries visited in recent years in Europe, Asia and Africa, is drunkenness looked upon as in any way but the natural consequence of their system of liquor control.

I agree that men, women and children there can drink and get drunk without interference and at slight cost, and the jollier they are the better it seems to suit. But even in Europe there are some things worth ramembering. At Potsdam I met an American, who stuck to me like a brother, and we went to Berlin, and he was bitter against American prohibition and said prohibition was a failure in the United States. He asserted that he lived in Chicago, and said that he had to go a mile and a half to get his beer, had to sneak in a back alley and enter a back door, pay fifty cents for a glass of beer and then run the risk of being poisoned. And he showed his preference for the Berlin method, for durIng our luncheon he drank five large steins of beer, and asserted that when he got to Paris he would get drunk. He extolled European methods, for they had no probibition laws, and he said that at the Riviera one could get drunk for a small sum, could sleep in public and not be disturbed while sleeping off the drunk. Of course we could repeal our Eighteenth Amendment and Volsteảd Law and then we would have no violations of law so far as booze is concerned.

Again, in most countries recently visited, there are few automobiles, and their need for traffic laws are not as ours, and many other problems could be mentioned to illustrate the differences between our countries and conditions in the Old World. 'Take their problem of radios, for illustration, where there are few sending stations and under the strictest restrictions, and few receiving stations and even they under the most rigid restrictions. I agree that the poverty of the people there interferes with their desire to have automobiles and receiving sets, but especially in the matter of the radio, they are hampered by rules and regulations that are almost prohibitive, and yet some people seem to think that Americans are oppressed and terribly hampered by laws, while other countries are free from impositions of law.

I assert, and from a visit to most of the countries of Europe, West Asia and Northern Africa, and under conditions favorable for investigations, that in none of them are conditions ideal, as some would have 
us believe, but on the contrary in none of them are conditions as favorable and conducive to prosperity and happiness as in the United States.

It is true that we have more laws, for we have a higher and better civilization, and greater prosperity, and so I give my hearty approval to the work that we did in the past, and believe that the present legislature is well qualified to legislate for the people of Iowa. They have had better opportunities for education and information than did we of a former generation, and I believe are better fitted for legislative work than were we. We did the best we knew. We may have made mistakes: and possibly we did, but we acted from conscientious motives, and I believe that the present legislature is fitted for the work before it, and am confident that they will do their work faithfully and well.

\section{ADDRESS OF THE PRESIDENT}

By George W. Clanke

I find that it was something more than twenty years ago that in an address at the State Fair Grounds I heard a distinguished speaker and lecturer, a widely known Iowan, say that the day of the pioneer in Iowa was past and that soon the last of the pioneers would be gone. Yet here we have today, twenty ycars after, a meeting of the Pioneer Lawmakers' Association of Iowa, very much alive, I shall assume, and having a provision in its constitution for its continual rejuvenation, which, if acted upon, insures its immortality. The Association to live its immortal life has only to have a seasonal influx of pioneers, and this has constitutional guaranty by the immortal state of Iowa in biennial sessions of the General Assembly, provided only the lawmaker, escaping the wrath of his constituents, survives his service through the dangers to which all flesh is heir, and surgical operations, for twenty years. All expectancies of life figured out by all the great insurance companies of America and Europe unite in the opinion that the influx, biennially, will be entirely sufficient to insure the immortality of the Association and of the individual pioneer. That the experience of the Association coincides with the mathematical conclusion of the companies is shown by the fact that the influx of eligible pioneers at this moment is at least forty-five. If, however, at any time through the unending cycle of years there should be danger of expiration of the Association for want of eligible, dyed-in-the-wool lawmakers, there yet remains a source of immortal eligibles consisting of all former "state officers, senators, and representatives in Congress from Iowa, United States supreme, circuit, and district judges, state boards of education, judges and district attorneys" and others, or such of them as survive the unforeseen, but inevitable risks and dangers to physical existence for a period of twenty years. They would all, of course, become pioneer lawmakers by adoption-the Association then combining in its personnel at once all the dignity, learning and rich and most highly valued experience coming from making, administering and interpreting the laws 
Copyright of Annals of Iowa is the property of State of Iowa, by \& through the State Historical Society of Iowa and its content may not be copied or emailed to multiple sites or posted to a listserv without the copyright holder's express written permission. However, users may print, download, or email articles for individual use. 